Markus Hiekkanen

\title{
AMBIGUITY AND THE REPRESENTATION OF AN AUTHORITY. A HERALDIC IMAGE OF LAURENTIUS MICHAELIS SUURPÄÄ, THE BISHOP OF TURKU?
}

The starting point for this article, which is dedicated to Kaur Alttoa, my friend since the late 1980s, is a photo of the choir window of the Tyrvää Church (Fig. 3). On the window arch besides a modified chevron ornament, we can see two images in red ochre. On the left, there is a cross with a six-pointed star beneath it. On the right, we can see a head of a human being, probably - at least in my opinion - a man, with long, curly hair pushing out from under the rim of a headdress or something that resembles one. The imagery is about as simple as it can get.

Tyrvää is one of the parishes of Satakunta in the medieval Diocese of Turku or present-day Finland (Fig. 2). It had been part of the parish of Sastamala since the first half of the $13^{\text {th }}$ century, but was established as a partially independent chapelric or chapel congregation, around 1400. A wooden church was built on a small island on the same spot where the stone church that still exists was later built during the summers between 1506 and 1516 . 


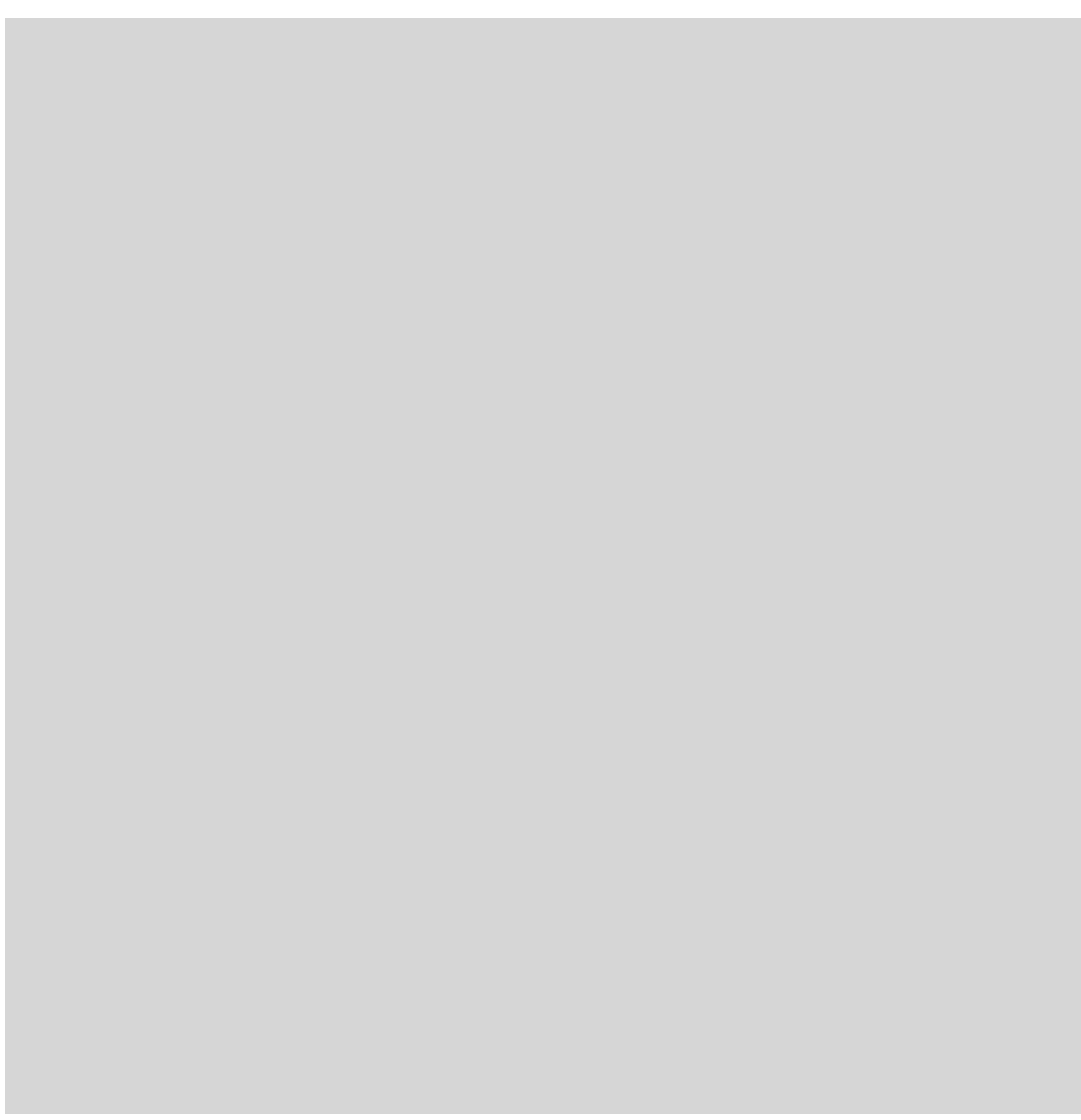

Fig. 1. View of the Tyrvää Church, as seen from ESE. Photo: Markus Hiekkanen (1997).

Because of a lack of funding, apparently partly due to the elimination of ecclesiastical taxation, mostly tithes, by the crown during the tumultuous years of the Reformation, the stone church was left unfinished. The planned brick vaults were never built. ${ }^{1}$ A little less than 500 years later, this would have devastating consequences when an arsonist set fire to the church. The flames rapidly spread

1 The plan for brick vaulting can be deduced by the existence of the attic stairway inside the northern wall of the nave and by the particular supporting structures on the upper portions of the nave walls, as well as the attic opening at a high location in the west gable. See research material and analysis of Tyrvää Church: Markus Hiekkanen, The Stone Churches of the Medieval Diocese of Turku. A Systematic Classification and Chronology (Helsinki. Suomen Mulnaismuistoyhdistys, 1994), 17, 83-84, 88, 132-134, 139-141, 157, 183, 185 (fig. 176 with the attic opening at a hig ocation in the gable), 374,396

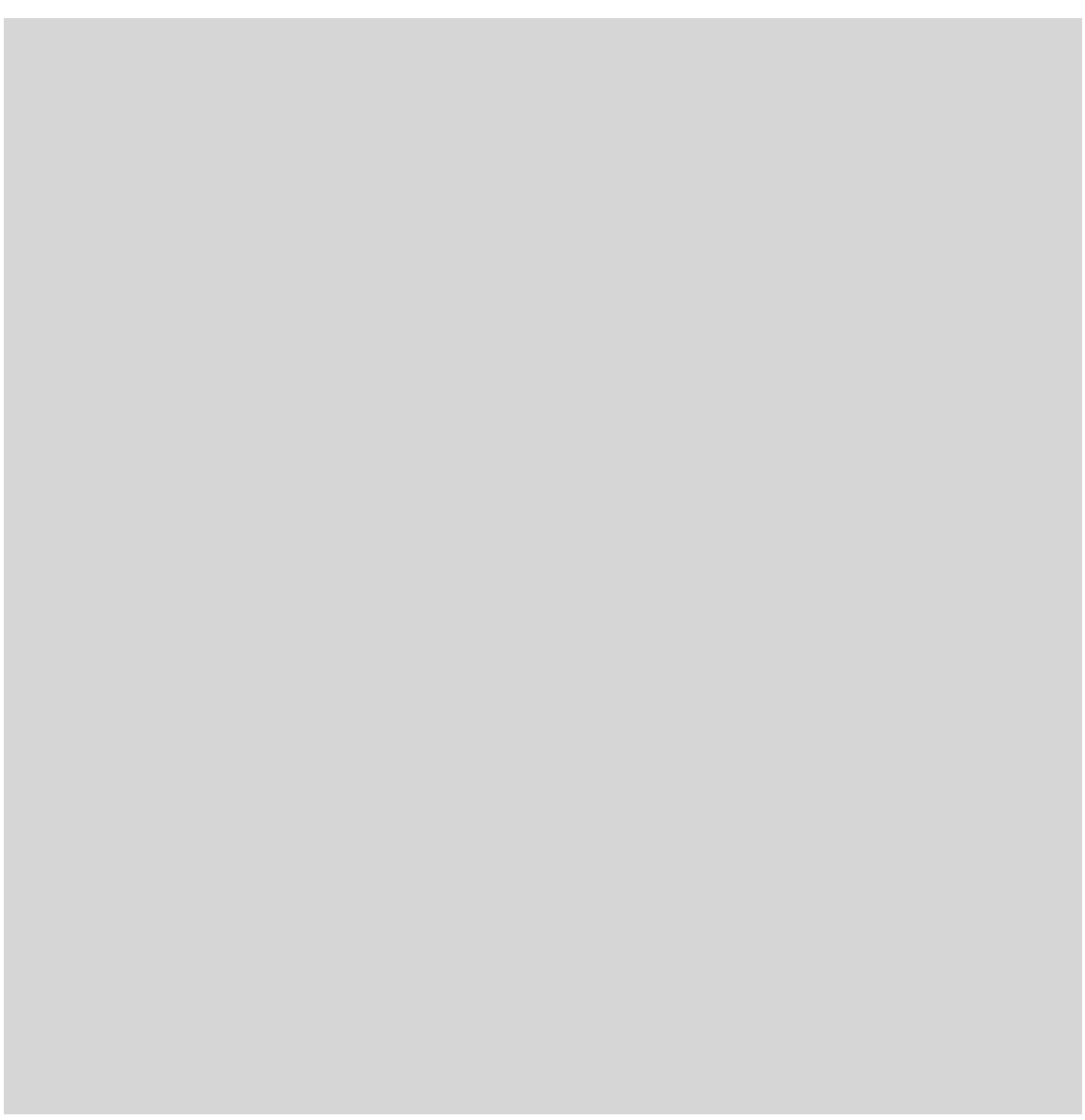

Fig. 2. Medieval stone churches in Denmark, Estonia, Finland, Norway, and Sweden. After Markus Hiekkanen, "Pohjoismaiden ja Viron kivikirkkojen levinneisyys keskiajan loppuun mennessä", Suomen historian kartasto, ed. by Pertti Haapala, Raisa Maria Toivo

through the plank vault destroying the exceptionally well preserved $17^{\text {th }}$ century interior and roof construction. ${ }^{2}$

After the fire, a thorough restoration was carried out during which fragments of wall paintings were found - exclusively on the outer walls ${ }^{3}$ (Fig. 1). Some of them had already been noticed in the early $20^{\text {th }}$ century, but also by the author a little earlier than the fire, in the course

2 Aino Niemi, Yhteistyöllä, taidolla ja tahdolla - Tyrvään Pyhän Olavin kirkon paanukattolathoot ja jatleenrakenus $1955-200$

3 Katja Fält, Wall Paintings, Workshops, and Visual Production in the Medieval Diocese of Turku from 1430 to 1540 (Helsinki: Suomen Muinaismuistoyhdistys, 2012), 77-78. 


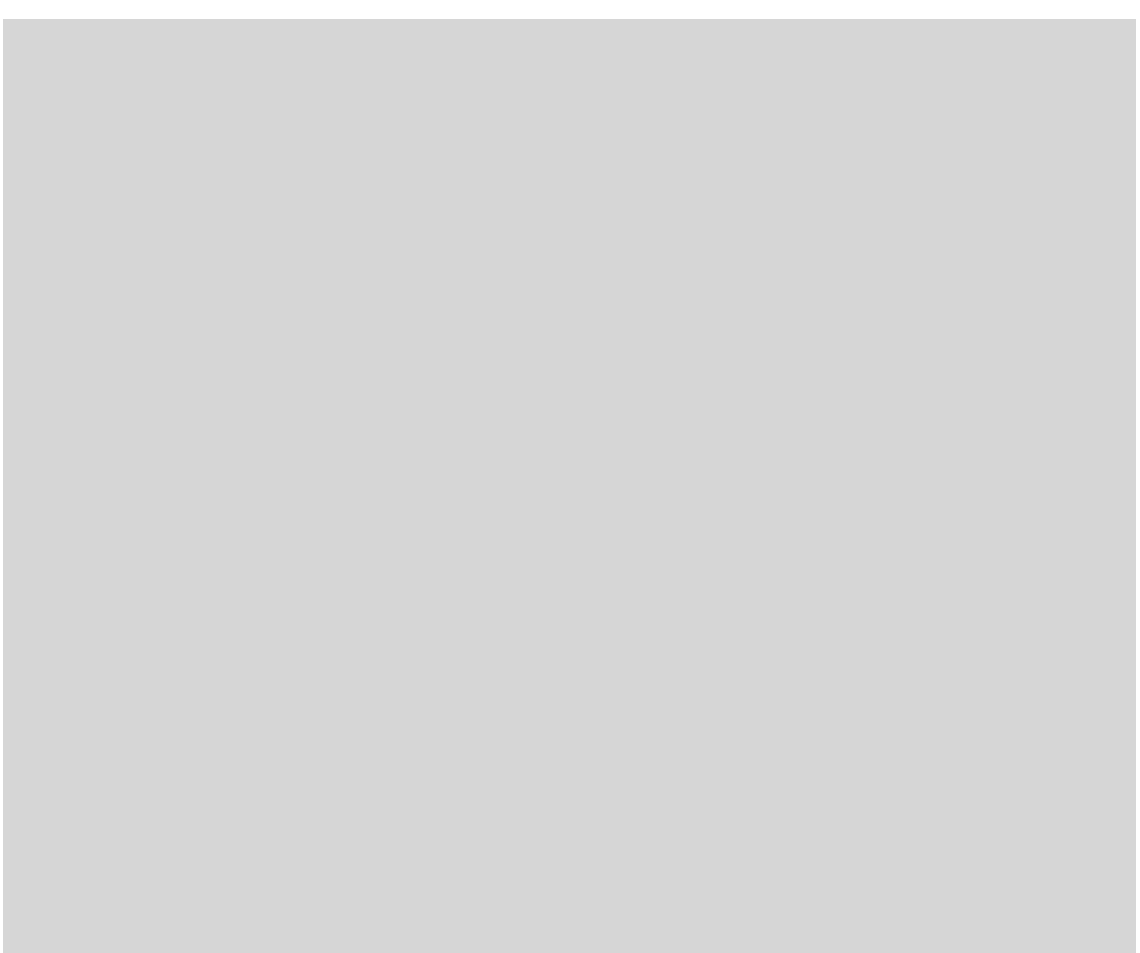

Fig. 3. Upper part of the chancel window of Tyrvää Church, Satakunta, Finland. Photo: Markus Hiekkanen (2003).

of reparation works in the church, for example, something resembling a consecration cross was found. ${ }^{4}$ During the conservation work after the fire, the cross-and-star combination and the man's head were also found.

All the fragments of the wall paintings in Tyrvää Church belong to a group which has a special place in the medieval art of Finland, and actually, of the Nordic countries. Since the 1930s or earlier they have been called "primitive paintings", a name that alludes to their technical inferiority compared to those made by professional painters. ${ }^{5}$ Currently

4 For the appearance of the chancel window in 1992, thus before the fire in 1997 with the following restoration work, see Hiekkanen, The Stone Churches of the Medieval Diocese of Turku, 59, fig. 52 .

5 Although the term "primitive paintings" is not used in the earliest descriptions and definitions, the connotation is clear enough when e.g. Eliel Aspelin describes the paintings of Nousiainen Church in Finland Proper as "made in a smudgy manner" and "odd" "töhrötekoisia", "outoja")
as well as "thrown together" ("kyhäykset"). Eliel Aspelin, Suomalaisen taiteen historia pääpiirteissään (Helsinki: Suomalaisen Kirjallisuuden Seura, 1891), 13. this name has given way to a more appropriate and perhaps less condescending term "builder paintings" or "master builder paintings".

Immediately after the wall painting fragments were found, the Greek cross and the star were interpreted as being an illustration of the Särkilahti (Swedish Särkilax or Stiernkors, depending on the cultural point of view) coat of arms. The lack of contours of the escutcheon (shield) was itself considered as not very important in this context, even though it was regarded as curious. This identification led to the following question: To whom does the coat of arms belong? Here again the answer came quite naturally, considering when the Tyrvää Church was built. The most likely candidate was Magnus Nicolai Särkilahti, the Bishop of Turku, whose term as the leader of the diocese was immediately before the stone church started to be built, namely from 1489 to 1500 when he died.

The man's head, for its part, which is painted without much elaboration, is ambiguous especially in regard to the object above or on the head. Is it a bishop's mitre? Or could it be interpreted as the nimbus (or halo) of a saint? Or is it a poor representation of the cap of a master builder? In a book on Finnish medieval churches in 2003, I presented a tentatively formulated interpretation according to which the man's face could be that of Bishop Magnus Särkilahti. ${ }^{7}$ Thus, it would have been a kind of portrait or rather a representation of the owner of the coat of arms.

It was only later that a new idea occurred to me. Although I had previously paid attention to the image of the longhaired man, it was in Kyllikki Männikkö's article ${ }^{8}$ about the themes of the coats of arms in the seals of the medieval Turku bishops, that I noticed a possible and intriguing connection to Bishop Laurentius Michaelis Suurpää. She uses the term "with lots of hair" (runsashiuksinen) in regard to the man's head in Suurpää's coat of arms on his armorial bearings. ${ }^{9}$ Soon after, but it seems, without any connection to the former, Eljas

6 For a comprehensive research history, see Fält, Wall Paintings, Workshops, and Visual Production in the Medieval Diocese of Turku from 1430 to 1540, 26-33.

7 Markus Hiekkanen, Suomen kivikirkot keskiajalla (Helsinki: Kustannusosakeyhtiö Otava, 003), 82; See also Markus Hiekkanen, Suomen keskiajan kivikirkot (Helsinki: Suomalaise Kirjallisuuden Seura, 2007), 263.

8 Kyllikki Männikkö, Vaakunan esiintyminen Turun keskiaikaisten piispojen sineteissä. Henkilö- ja sukuvaakunat Suomessa, ed. by Antti Matikkala, Wilhelm Brummer (Helsinki Suomalaisen Kirjallisuuden Seura, 2011), 37-48.

9 Ibidem, 44-46. 
Orrman published an article about the heraldry of clerical coats of arms in Finland during the Middle Ages. ${ }^{10}$

Orrman as well as Männikkö note that Laurentius Michaelis Suurpää was not of noble birth but the son of a rich merchant in Turku. ${ }^{11}$ Accordingly, his family did not have a coat of arms, and thus, as a canon of the Turku chapter he did not bear a coat of arms but was referred to as St. Laurentius. It was only when he became bishop that a personal coat of arms appears on his bishop's seal. Orrman describes it as follows: a man's head en face with curly hair that alludes to the family name Suurpää (large head). ${ }^{12}$ As noted above, this pictorial motif is described by Kyllikki Männikkö in approximately the same way. ${ }^{13}$

In his doctoral dissertation in 2009, Visa Immonen mentions two donations made by Laurentius Suurpää, namely from the churches of Uusikaarlepyy and Rusko. ${ }^{14}$ The chalice from the Uusikaarlepyy Church in Southern Ostrobothnia was apparently owned by the Cathedral of Turku until the $17^{\text {th }}$ century when it was either sold or donated to the given congregation. On the foot of the chalice, St Laurentius with his gridiron is engraved in the usual manner. In his right hand the saint is holding a coat of arms on which a man's head is engraved in profile. Compared to most other representations of the men of the time, the man has conspicuously long hair. It is combed back, which is not unheard of when an individual is projecting a kind of power image of him- or herself ${ }^{15}$ (Fig. 4). Even here, the contrast

10 Eljas Orrman, "Iakttagelser om den kyrkliga heraldiken i Finland under medeltiden och om dess nyttjande i olika kontexter", Heraldisk Tidsskrift, Bd. 11, 108 (2013), 337-263.

11 This, of course, is has also been noted in earlier research about Bishop Suurpää. See: Carl Axel Nordman, Finlands medeltida konsthantverk (Helsingfors: Museiverket, 1980), 20-24; Markku Koponen, Heraldica catholica Fennica (Helsinki: Partioheraldikot ry, 1984), 34-35 Seppo Suvanto, "Laurentius Michaelis Suurpää", Kansallisbiografia-v

12 "[E]tt lockigt manshuvud en face som alluderar till släktnamnet Suurpää (storhuvud)". ( Orrman, "lakttagelser om den kyrkliga heraldiken i Finland under medeltiden och om des

13 "Vaakunakuvan aihe on Suurpään puhuva tunnus: runsashiuksinen ihmisen (miehen) pää" Männikkö, Vaakunan esiintyminen Turun keskiaikaisten piispojen sineteissä, 45.

14 Visa Immonen, Golden Moments: Artefacts of Precious Metals as Products of Luxury Society for Medieval Archaeology in Finland, 2009), 31-33 (Uusikaarlepyy), 34-35 (Rusko). He kindly sent me photos of the objects that are of interest in the context of the paper, and for this I would like to express my gratitude.

15 From the $19^{\text {th }}$ and $20^{\text {th }}$ century Western culture of hairstyles, the images of Jacqueline Kennedy and Karl Marx are distant but still easily recognizable in this sense.

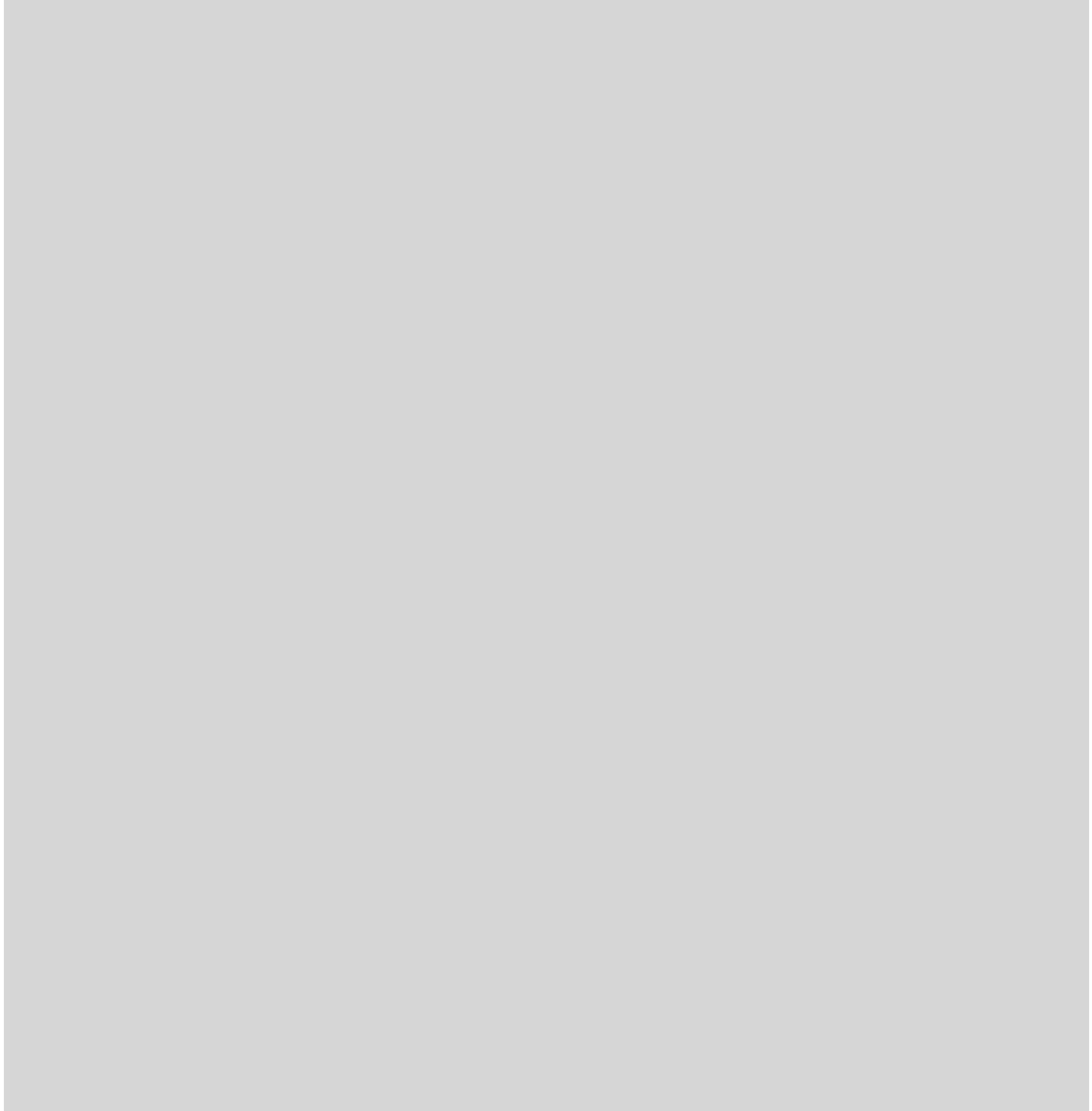

Fig. 4. Probable engraved image of Bishop Laurentius Suurpää on the foot of the Uusikaarlepyy chalice. Photo: Visa Immonen.

to the general hairstyle of the day, with the hair generally combed to the sides and/or to the front, is conspicuous.

In a photo of the chalice of Rusko Church attention is drawn to what seems to be the bishop's intentionally coiffed long hair (Fig. 5). In the engraving, the bishop is depicted en face which makes the long hairstyle stand out. The form and size of the skull itself is proportionate, at least, to his neck, but the coiffure - as if the hair was being blown back by a strong wind - is prominent.

Thus, the prerequisites emerge of the images on the arch of the choir window in the Tyrvää Church, which might possibly present a new perspective that differs from the earlier interpretation. Perhaps 
the man's head is not a portrait or an image of Bishop Magnus Särkilahti, but meant to be an illustration of the coat of arms without the contours of an escutcheon of the family of Särkilahti. Instead it might be a part of another coat of arms, which would make the whole painting a variation of an alliance coat of arms. Thus, one part of the alliance is the family shield of Magnus Nicolai Särkilahti and the other the individual coat of arms of Laurentius Michaelis Suurpää, depicting his characteristic feature, namely his head with long hair The interpretation merits discussion because the entire painting, in which at least the coat of arms of the Särkilahti family is present while contours of the escutcheon are missing (and which, actually according to the heraldic rules, is not needed), would be unbalanced and difficult to explain without the principle of symmetry.

When interpreted in this way the discrepancy between the two images, namely the coat of arms of the Särkilahti family and that of a face, disappears. In fact, both images, and not only that of the Särkilahti coat of arms, can be tentatively regarded as illustrations of coats of arms, but without the contours of the shield.

I cannot give any reason for the lack of the contours, but one thing is clear: among the wall paintings made by builders in the Diocese of Turku, many are obscure and incoherent, even twisted, if I may say so, images which are not easy to interpret, to say the least. Among them the images, at least tentatively interpreted as escutcheons with coat of arms, in the churches of Maaria, Nousiainen, Pernaja, and Pyhtää, are excellent examples of this kind of imagery. ${ }^{16}$

I want to stress that what I have presented is a tentative interpretation, the premises of which are somewhat vague. For instance, is the combination cross-cum-star really meant to be an illustration of the coat of arms of the Särkilahti family? Are we aware of all the paintings that originally appeared on the window sills and the arch of the Tyrvää choir window? Is the interpretation of the man's head as a bishop with his mitre valid

16 See e.g. Camilla Ahlström-Taavitsainen, "Vapenbilder bland kalkmålningarna i Finland medeltidskyrkor", Helsingin yliopiston taidehistorian laitoksen julkaisuja VIII (1984), passim; Markus Hiekkanen, "Vase-suvun vaakuna Pernajan kirkossa?", SKAS, 1 (1998), 12-13; Marku Hiekkanen, "Henkilövaakunat keskiaikaisissa kirkoissa", Henkilö- ja sukuvaakunat Suomessa ed. by Antti Matikkala, Wikhelm Brummer. Suomalaisen Kifjallisuuden Seuran Toimituksia 1323 (Helsinki, 2011), 49-75; Fält, Wall Paintings, Workshops, and Visual Production in the Medieval Diocese of Turku from 1430 to 1540, passim.

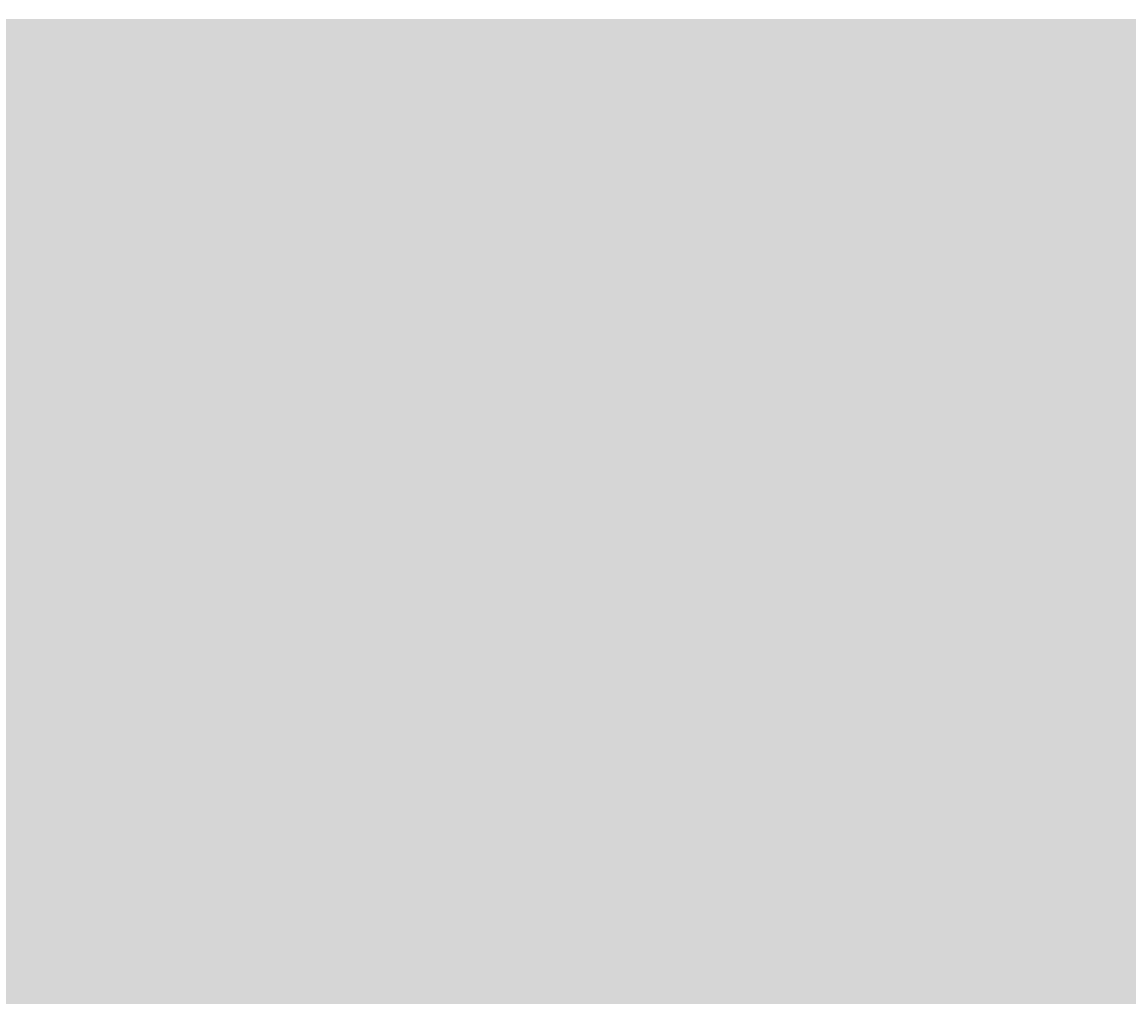

Fig. 5. Probable engraved image of Bishop Laurentius Suurpää on the foot of the Rusko chalice. Photo: Visa Immonen.

or should it be interpreted as a saint with a halo? Thus, several questions remain.

One further aspect should be examined. If we assume that the interpretation presented here is correct and that we see before us two coats of arms as an alliance coat of arms of the two bishops of Turku Diocese in the outer window arch, what might they have stood for? We know that Magnus Nicolai Särkilax held the office of Bishop of Turku between 1490 and 1500 while Laurentius Michaelis Suurpää held the same position from 1500 to 1506. At least the physical connection of the depictions with the stone church seems to be obvious because we know with certainty that the construction of the stone church Tyrvää was started in 1506, or 1507 at the latest. Thus, the two bishops immediately preceding the actual building of the stone church are depicted on the outer arch of the chancel window. 
We also know from other sources, and it is also common knowledge, that before any major building work was started, a period of planning, negotiations to obtain building permits, and discussions and contracting with the master builder and other experts, as well as the accumulation of funds, must have preceded it. This could, depending on the size and complexity of the building, take more or less time, e.g. five or twenty years or something between. If we keep this in mind, the two bishops could very well be the ones who, as the authorities of the Turku Diocese, initiated the construction project for the stone Tyrvää Church and kept it moving.

I do not mean that they would in any way have financially supported the building project itself but they played a role as the religious and administrative leaders, and thus symbols of the entire Diocese of Turku. In fact, the paintings could, more or less, be interpreted as memorial images of the two dead bishops during the time they were in charge of initiating and organising the construction of stone church in the Diocese of Turku.

Why, then is there no image referring to the bishop that was in office when the building was completed, and its functional parts and the paintings were completed. The date is known, namely 1516. Arvidus Kurck, who was inaugurated in 1510 and perished in a shipwreck in Öregrund in the autumn of 1522, was the Bishop of Turku at that time. Here I can only suggest some possibilities, one of which is that his coat of arms was painted either on the outer or the inner wall of the building (or even on the same chancel window arch as the surviving ones), but has since been lost.

To conclude, in this article I have tackled one aspect of a problem, namely the builder paintings of the Finnish stone churches, which, by virtue of their nature are very difficult to interpret. Thus, we have very little to grasp hold of. Still, I think it worthwhile. The steps taken seem to grow shorter and shorter the more we study the visual world of the Middle Ages. Nevertheless, I have come to a tentative interpretation and leave it to the scientific community to discuss the topic in the future: how to interpret the images of the chancel window arch of the Tyrvää Church?
Markus HiekKanen: Ambiguity and the Representation of an Authority. A Heraldic Image of Laurentius Michaelis SuurpäÄ, The Bishop of Turku?

Keywords: SuUrpä̈̈ Family; Stiernkors/Särkilahti family; EXTERIOR WALL PAINTINGS; BUILDER PAINTINGS; ESCUTCHEON; COAT OF ARMS

\section{CV}

Markus Hiekkanen (b. 1949), PhD, Professor, retired from the University of Helsinki. He has studied medieval and early modern period towns, churches, artefacts in the fields of archaeology, art history, and history since the 1970s. He has published several monographs and articles as well as other publications. 
